\title{
ANALISIS FAIRNESS DAN INCENTIVE CONTRACTING PADA KINERJA BERBASIS ANGGARAN ATAS PENGUJIAN: EKSPERIMEN (STUDI KASUS PADA MAHASISWA PASCASARJANA DIUNIVERSITAS MALIKUSSALEH TANUN 2017- 2018)
}

\author{
Hendra Raza ${ }^{1}$, Cut Fauziah ${ }^{2}$ \\ ${ }^{1,2}$ Prodi Akuntansi Fakultas Ekonomi dan Bisnis Universitas Malikussaleh Lhokseumawe \\ hendraraza@unimal.ac.id
}

\begin{abstract}
This study aimed to determine the analysis of fairness and incentive contracting on performancebased budget testing experiments. The data used in this research were primary data. The population in this study consisted of 59 postgraduate students who were on Lancang Garam St, postgraduate campus of Malikussaleh University with an observation period starting from 2017-2018. The sampling method was purposive sampling. The number of samples that meet the research criteria based on existing considerations was that all postgraduate students management in science during 2017-2018 as many as 59 respondents. The method used to analyze the relationship between independent variables and the dependent variable was Multiple linear regression analysis and Classical assumption test. The test results showed that the planning variable was accepted because the value was significantly higher, namely the difference between fairness and budget-based performance, while the other side is accepted also because it was seen from a significantly higher value that was with the difference between fairness towards the budget process, which has been studied from 59 students on the postgraduate campus of Malikussaleh University.
\end{abstract}

Keywords: Fairness, Budget-Based Performance, Budget Process.

\section{PENDAHULUAN}

Disuatu organisasi anggaran merupakan salah satu alat ukur kinerja menejer divisi. Dalam hal ini anggran berfungsi untuk memotivasi dan mengevaluasi kinerja menejer-menejer divisi (merchan 1998) anggaran dapat menjadi alat penilayan kinerja exsekutif yang dinilai berdasarkan pencapayan target anggaran dan efisiensi anggaran selain itu anggaran sebagai alat memotivasi manajer,dan stafnya agar berkerja secara ekonomis, ekfektif, dan efisien dalam mencapai target dan tujuan organisasi yang telah ditetapkan. anggaran dapat menjadi motivasi jika dihubungan dengan evaluasi kinerja organisasi dan sistem kompensasi (hopwood 1972).pencapaian target anggaran baik dalam waktu dan kuantitas yang telah ditetapkan merupakan bentuk prestasi yang semestinya menberikan penghargaan.

Setiap organisasi mengharapkan agar anggaran yang telah ditetapkan dapat dicapai. Namun penentuan target ang garan dan proses penetapannya merupakan dua faktor penting yang harus diperhatikan. Secara umum, seseorang akan membandingkan anggaran yang ditetapkan atas dirinya dengan pihak lain yang setara. Hal ini menimbulkan persepsi keadilan atas target maupun proses penentuannya. Dengan demikian persepsi keadilan ini menjadi pendorong untuk berkinerja dengan baik. Persepsi individu terhadap fairness atau keadilan baik dalam target maupun prosesnya menjadi motivasi bagi individu untuk mencapai anggaran yang telah ditetapkan (Libby 1999; dkk et. all).

Bernardin dan Rulssel (1993) dalam Yeremias T. Keban (2004) mengartikan kinerja sebagai the record of outcomes produced on a specified job function or activity duringa specified time period. Dalam definisi ini, aspek yang ditekankan oleh kedua pengarang tersebut adalah catatan tentang outcome atau hasil akhir yang diperoleh setelah suatu perkerjaan atau aktivitas dijalankan selama kurang waktu tertentu. Dengan demikian kinerja hanya mengacu pada serangkaian hasil yang diperoleh seorang pengawai selama periode tertentu dan tidak termasuk karakteristik pribadipegawai yang dinilai.

Kinerja berbasis anggaran adalah penetapan kinerja yang didasarkan pada ketersediaan anggaran.kinerjalah yang di ubah-ubah sesuai dengan anggaran tertentu artinya: anggaran bersifat tetap dan menjdi dasar dari penentuan target kerja.

Fairness merupakan perlakuan yang adil dan setara dalam memenuhi hak-hak stakeholder yang timbul berdasarkan perjanjian sertara peraturan perundangan yang berlaku. Fairness juga mencakup adanya kejelasan hak-hak pemodal, sistem hukum dan penegakan peraturan untuk melindungi hak- 
hak investor, khususnya pemeggang saham minoritas dari berbagai bentuk kecurangan. Fairness diharapkam membuat seluruh aset perusahaan di kelola secara baik dan hatihati.sehinnga muncul perlindungan kepentinggan pemenggang saham secara fair (jujur dan adil).

Hubungan Fairness terhadap kinerja berbasis anggaran adalah semakin adil suatu perusahaan dalam memberikan income (berupa gaji atau reward) yang sesuai dengan outcame (kinerja karyawan) maka karyawan tersebut akan merasakan puas dan termotivasi dalam meningkatkan kinerjanya. Baik dari proses penetapan anggaran maupun pencapaian anggaran.

Menurut Folger (1986), ketika target anggaran ditentukan secara fair, maka informasi mengenai proses penentuannya menjadi tidak penting dalam memotivasi pencapaian target. Dilain pihak, ketika target anggaran ditentukan dengan unfair, maka individu akan berusaha mencari informasi mengenai bagaimana proses penentuan target anggaran tersebut. Jika hal itu dihasilkan dari proses yang tidak fair, maka individu menjadi merasa sangat marah, sehingga kurang termotivasi unt uk mencapai target anggaran (Cropanzano dan Folger 1991).

Salah satu teori yang menguji mengenai fairness adalah teori Referent Cognitions. Referent cognition theoryyaitu teori untuk menguji fairness, jadi dengan teori ini kita dapat mengetahui interaksi antara fairness terhadap target anggaran dan fairness pada proses penentuan anggaran sehingga menimbulkan motivasi dalam mencapai anggaran. Menurut teori referent cognitions, interaksi antara fairness terhadap target anggaran dan fairness pada proses penentuan target anggaran merupakan perpaduan yang dapat menimbulkan motivasi dalam mencapai anggaran.

Fenomena yang terjadi yaitu setiap perusahaan ataupun organisasi mengharapkan anggaran yang telah ditetapkan dapat dicapai. Tetapi terkadang target anggaran yang telah ditentukan tidak sesuai dengan target anggaran yang ingin dicapai. Namun, dalam mencapai target maupun proses anggarannya dalam menentukan target anggaran, seseorang akan membandingkan anggaran yang ditetapkan atas dirinya dengan pihak lain yang setara. Dengan kata lain, anggapan seseorang terhadap fairness dalam menentukan target maupun proses targetnya akan menjadi motivasi bagi seseorang tersebut dalam mencapai anggaran yang telah ditetapkan. Sehingga, ketika penentuan target anggaran yang ditentukan dengan tidak wajar atau unfair, maka seseorang tersebut akan merasa marah dan merasa tidak adil, sehingga seseorang tersebut kurang termotivasi untuk mencapai target anggaran.

Penelitian ini bertujuan menguji bagaimna interaksi antara persepsi fairness dan insentif yang dijanjikan dalam memotivasi individu untuk berkinerja dalam mencapai target anggaran.
Melalui metode eksperimen, fairnessterhadap target anggaran dimanipulasi pada target yang fairjika dapat dicapai (attainable) dan target yang unfairjika tidak dapat dicapai (unattainable). Fairnessdalam proses pencapaian target meliputi dua elemen yaitu tingkat dimana target anggaran dibandingkan dengan target pihak lain (referent) dan fairness pada proses penentuan budget itu sendiri. Pada penelitian ini, manipulasi fairness terhadap proses penentuan target anggaran yang ditetapkan untuk pihak lain adalah equal (fair) dan higher (unfair) dibandingkan yang ditetapkan untuk dirinya.

Penelitaan sebelumnya, hasil penelitian yang dilakukan oleh Libby (2001) yang menemukan bahwa kinerja rendah ketika target dan proses penentuan anggaran dilakukan secara tidak adil. Fair budget target menyebabkan tidak adanya perbedaan kinerja antara anggaran yang ditentukan secara adil maupun tidak. Sedangkan proses yang fair tidak memberikan dampak yang berbeda terhadap kinerja dengan target yang adil maupun tidak.

Adapun rumusan masalah dalam penelitian ini adalah:

1. Apakah Analisis fairness mempengaruhi pada kinerja berbasis Anggaran?

2.Apakah Incentinve Contracting mempengaruhi pada kinerja berbasis Anggaran?

3.Apakah Analisis fairness dan Incentinve Contrcting mempengaruhi pada kinerja berbasis Anggaran?

Sedangkan tujuan penelitian adalah:

1. Untuk mengetahui pengaruh Analisis fairness mempengaruhi pada kinerja berbasis Anggaran.

2. Untuk mengetahui pengaruh Incentinve Contracting mempengaruhi pada kinerja berbasis Anggaran.

3. Untuk mengetahui pengaruh Analisis fairness dan Incentinve Contracting mempengaruhi pada kinerja berbasis Anggaran.

\section{TINJAUAN PUSTAKA}

\section{Teori Keadilan}

Teori keadilan pertama kali dipopulerkan oleh J Stacy Adam tahun 1963. Teori ini menganggap bahwa individu membandingkan masukan dan keluaran pekerjaan mereka dengan masukan atau keluaran orang lain dan kemudian berespon untuk menghapuskan setiap ketidakadilan (Ikhsan A dan Iskhak M, 2005). Peran Keadilan selama anggaran telah difokuskan pada penelitian akuntansi perilaku, seperti penelitian Lindquist (1995) yang menemukan bahwa suatu organisasi cenderung ingin mempertahankan keadilan dalam proses anggaran. 
Keadilan telah dinyatakan sebagai cara untuk memecahkan konflik, menyeleksi pegawai, menyelesaikan perselisihan tenaga kerja, negoisasi gaji (Greenberg, 1986) Pendekatan yang dilakukan dengan cara yang berbeda terhadap keadilan akan sangat berguna untuk menjelaskan bermacam perilaku dalam konteks organisasi pada saat ini. Berdasarkan teori keadilan, bila karyawan mempersepsikan suatu ketidakadilan mereka dapat meramalkan untuk mengambil salah satu dari enam pilihan yaitu: mengubah masukan, mengubah keluaran, mendistorsikan persepsi mengenai diri, mendistorsi persepsi mengenai orang lain, memilih acuan yang berlainan dan meninggalkan (Robbin PS, 2003).

\section{Kinerja Berbasis Anggaran}

Penganggaran berbasis kinerja (performancebased budgeting) merupakan suatu pendekatan sistematis dalam penyusunan anggaran yang mengaitkan pengeluaran yang dilakukan organisasi sektor publik dengan kinerja yang dihasilkannya dengan menggunakan informasi kinerja. Performance budgeting mengalokasikan sumber daya pada program, bukan unit organisasi semata, dan memakai output measurement sebagai indikator kinerja organisasi. Pengkaitan biaya dengan output organisasi merupakan bagian integral dalam berkas atau dokumen anggaran. Sejalan dengan pengertian dan tujuannya, Robinson dan Last (2009) menyatakan persyaratan mendasar dalam penerapan bentuk sederhana penganggaran berbasis kinerja (performance-based budgeting), adalah:

1.Informasi mengenai sasaran dan hasil dari pengeluaran pemerintah dalam bentuk indikator kinerja dan evaluasi program sederhana, dan

2.Proses penyusunan anggaran yang dirangcang untuk memfasilitasi penggunaan informasi tersebut.

\section{Definisi Fairness}

Fairness adalah suatu keseteraan dan kewajaran dalam perlakuan adil dan setara dalam memenuhi hak-hak stakeholder yang timbul berdasarkan perjanjian serta peraturan perundang-undang yang berlaku.

Menurut teori Referent Cognitions, interaksi antara fairness terhadap target anggaran dan fairness pada proses penentuan target anggaran merupakan perpaduan yang dapat menimbulkan motivasi dalam mencapai anggaran. Fairness dalam proses pencapaian target meliputi dua elemen yaitu tingkat dimana target anggaran dibandingkan dengan target pihak lain (referent) dan fairness pada proses penentuan budget itu sendiri. konsep fairness baik dalam penetapan target anggaran maupun proses penentuannya, memberikan dampak yang cukup signifikan dalam upaya memotivasi manajer-manajer divisi untuk memberikan kinerja terbaik mereka.
Menurut Folger (1986) dalam Yusnaini (2010), ketika target anggaran ditentukan secara fair, maka informasi mengenai proses penentuannya menjadi tidak penting dalam memotivasi pencapaian target. Dilain pihak, ketika target anggaran ditetnukan dengan tidak adil, maka individu akan berusaha mencari informasi mengenai bagaimana proses penentuan target anggaran tersebut. Jika hal itu dihasilkan dari proses yang tidak fair, maka individu menjadi merasa sangat marah, sehingga kurang termotivasi untuk mencapai target anggaran (Cropanzona dan Folger, 1991 dalam Yusnaini, 2010).

Fairness dalam proses pencapaian target meliputi dua elemen yaitu tingkat dimana target anggaran dibandingkan dengan target pihak lain (referent) dan fairness pada proses penentuan budget itu sendiri. Pada penelitian ini, manipulasi fairness terhadap proses penentuan target anggaran yang ditetapkan untuk pihak lain adalah equal (fair) dan higher (unfair) dibandingkan yang ditetapkan untuk dirinya.

\section{Incentive Contracting}

incentive contracting adalah suatu pemilih yang member kompensasi tahapan kepada kontraktor berdasarkan kinerja eksekusi biaya, jadwal, kualitas, dan keamanan sesuai dengan persyaratan dan ketentuan kontrak, ada dua kemungkinan insentiv harga tetap, dan kontrak insentiv penggantian biaya kontrak insentiv harga tetap lebih disukai bila biayanya melampaui persyartan kinerja yang dimana biaya target, harga, atau biaya suatu keuntungan digunakan sebagai titik tolak berbagai insentiv moneter dengan jumlah maksimu, setelah menyesesaikan kontrak, pembayaran insentiv dihitung berdasarkan biaya aktual kontraktor ditambah dengan skala keuntungan yang melandai keuntungan yang maksimal, keuntungannya bervariasi secara langsung atau jika terjadi biaya (underrun) atau berbandingan terbalik atau pun apabila terjadi berbandingan terbalik pada (overrun biaya) dengan selisih antara biaya kontrak dan biaya yang diijinkan dengan maksimum.

penelitian ini bertujuan menguji bagaimana interaksi antara persepsi fairness dan insentif yang dijanjikan dalam memotivasi individu untuk berkinerja dalam mencapai target anggaran. melalui metode eksperimen, fairness terhadap target anggaran dimanipulasi pada target yang fair jika dapat dicapai (attainable) dan target yang unfair jika tidak dapat dicapai (unattainable). fairness dalam proses pencapaian target meliputi dua elemen yaitu tingkat dimana target anggaran dibandingkan dengan target pihak lain (referent) dan fairness pada proses penentuan budget itu sendiri. pada penelitian ini, manipulasi fairness terhadap proses penentuan target anggaran yang ditetapkan untuk pihak lain adalah equal (fair) dan 
higher (unfair) dibandingkan yang ditetapkan untuk dirinya.

untuk memanipulasi kondisi pencapaian kinerja berdasarkan anggaran dengan incentive contracting, peneliti mengilustrasikan bahwa setiap anggota yang mampu mencapai target menterjemahkan kata dengan benar maka akan diberikan bonus tertentu. selain itu, anggota tim juga akan mendapatkan bonus tambahan untuk setiap kata yang mampu diterjemahkan dengan benar. hal ini diharapkan mampu memotivasi individu untuk berkinerja dengan baik dalam mencapai target anggaran meskipun organisasi tidak mampu memenuhi konsep fairness.

\section{Kerangka Konseptual}

Dapat dirumuskan kerangka pemikiran bahwa "Keadilan prosedural menjadi anteseden atau pemicu dari penyusunan anggaran secara partisipatoris sehingga ada kecenderungan bahwa keadilan prosedural berhubungan positif dengan partisipasi anggaran. Semua manfaat dari partisipasi cenderung mengarah pada bentuk kesepakatan yang makin besar pada gaya evaluasi yang digunakan perusahaan untuk meningkatkan kinerja manajerial sehingga partisipasi anggaran cenderung berhubungan positif dengan kinerja manajerial. Sehingga pengaruh dari keadilan prosedural terhadap kinerja manajerial dapat dihubungkan secara langsung atau tidak langsung.

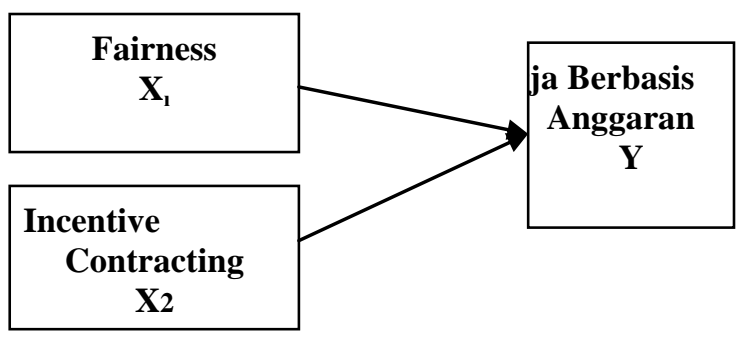

\section{Gambar 1. Kerangka Penelitian}

penjelasan kerangka fikir teoritis adalah untuk mengetahui bagaimana hubungan fairnessdan incentive contracting terhadap kinerja berbasis anggaran.

Hubungan fairness terhadap kinerjaberbasis anggaran adalah semakin adil suatu perusahaan dalam memberikan income (berupagaji atau reward) yang sesuai dengan outcome (kinerjakaryawan) maka karyawan tersebut akanmerasakan kepuasan dan termotivasi dalammeningkatkan kinerjanya, baik dari prosespenetapan anggaran maupun pencapaiyananggaran. dan hubungan incentive contractingpada kinerja berbasis anggaran adalah di lihat padaseberapa besar kompensasi yang di berikan, sesuaitidak dengan kontrak dan syaratsyarat karyawan berkerja. jadi semakin tinnggi kompensasi yang di berikan kepada karyawan maka akan memotivasikaryawan tersebut dalam menentukan prosesanggaran, sehingga mencapai suatu target anggaranyang telah ditetapkan. H1:Terdapat pengaruh antara fairness terhadap target anggaran.H2: Terdapat pengaruh antara fairness terhadap proses penetapan anggaran.H3: Terdapat pengaruh antara incentive contracting terhadap penetapan dan proses anggaran.

\section{METODE PENELITIAN}

Populasi yang digunakan dalam penelitian ini adalah seluruh mahasiswa pascasarjana yang terdaftar di Universitas Malikussaleh dijurusan manajemen tahun angkatan 2017/2018 yaitu sebanyak 59 Mahasiswa Program Pascasarjana Ilmu Manajemen (PPIM) yang dimana laki-laki sebanyak 38 orang sedangkan perempuan hannya 21 orang, dan lokasi penelitian yang berada di $\mathrm{Jl}$. Lancang Garam, Kampus Pascasarjana Universitas Malikussaleh.

Penentuan sampel dalam penelitian ini bagian dari jumlah dan karakteristik yang dimiliki oleh populasi tersebut. Sehingga sampel merupakan bagian dari populasi yang ada, sehingga untuk pengambilan sampel harus menggunakan cara tertentu yang didasarkan oleh pertimbanganpertimbangan yang ada yaitu seluruh mahasiswa pascasarajana ilmu manajemen angkatan tahun 2017/2018 sebanyak 59 responden.

\section{Design Penelitian}

Penelitian ini menggunakan desain eksperimen untuk menginvestigasi hipotesis yang diajukan. Eksperimen penelitian didesain dengan two by two (2x2) factorial design dan between subject. Dalam hal ini desain menggunakan persepsi fairness yang untuk penentuan budget target dan budget process. Budget target dianggap fair ketika individu merasa mampu untuk mencapai target yang telah ditetapkan. Sedangkan budget process dianggap fair ketika individu diberikan target yang lebih sama dengan pihak lain yang setara (referent) dan keputusan diambil melalui pertimbangan awal akan kemampuan individu dalam mencapai target.

Penelitimemanipulasidua level dari budget target yaitu fair budget target dimanipulasidengan attainability (dapatdicapai), sedangkan unfair budget target dimanipulasidengan unattainability (sulitdicapai). Untuk fairness pada budget process penelitimemanipulasipadadua level yaitu equal dan higher ketikadibandingkandengan target yang ditetapkanuntukpihak lain (referent).

Tabel1.DesainEksperimen $2 \times 2$ betweensubject

\begin{tabular}{|c|c|c|}
\hline \multirow{2}{*}{$\begin{array}{c}\text { Fairness of } \\
\text { Budget Target }\end{array}$} & \multicolumn{2}{|c|}{$\begin{array}{c}\text { Fairness of Budget } \\
\text { Proces }\end{array}$} \\
\cline { 2 - 3 } & $\begin{array}{c}\text { Equal } \\
\text { (Fair) }\end{array}$ & $\begin{array}{c}\text { High } \\
\text { (Unfair) }\end{array}$ \\
\hline
\end{tabular}




\begin{tabular}{|c|c|c|}
\hline $\begin{array}{c}\text { Attainability } \\
\text { (Fair) }\end{array}$ & $\mathrm{A}$ & $\mathrm{B}$ \\
\hline $\begin{array}{c}\text { Unattainability } \\
\text { (Unfair) }\end{array}$ & $\mathrm{N}$ & $\mathrm{N}=15$ \\
& $\mathrm{~N}=15$ & $\mathrm{~N}=14$ \\
\hline
\end{tabular}

Pada kondisi A, partisipan mendapatkan treatmen fair budget target (attainable) dan fair budget process (equal dibandingkan referent). Kondisi B dibentuk dengan fair budget target (attainable) dan unfair budget process (higher dibanding referent). Sedangkan pad a kondisi C, partisipan mendapatkan unfair budget target (unattainable) dan fair budget process (equal dengan referent). Pada kondisi D, partisipan dibentuk dengan unfair budget target (unattainable) dan unfair budget process (higher dibanding referent). Dapat dilihat pada Tabel 2.1 bahwa responden yang diberikan treatmen berjumlah 59 orang yang dikondisikan pada empat kelompok perlakuan. Dari jumlah tersebut yang mendapatkan perlakuan pada kondisi A sebanyak 15 orang, kondisi B sebanyak 15 orang, kondisi C sebanyak 15 orang dan kondisi D sebanyak 14 orang.

\section{HASIL PENGUJIAN KUALITAS DATA}

\section{Hasil Uji Validitas}

Uji validitas digunakan untuk mengukur sahat autidaknya suatu kuisioner. Suatu kuisioner dikatakan valid jika pertayaan pada kuisioner mampu untuk mengungkapkan sesuatu dengan menggunakan koefisien korelasi pearson, yaitu dengan menghitung korelasi antar skor masingmasing butir pertanyaan dengan skor (Ghozali, 2002). Batasan pengujian adalah bila koefisien koelasi signifikan pada tingkat signifikansi 0,05 maka data yang di tanyakan dikatakan valid. Pengujianva liditas dari instrument penelitian dilakukan dengan menghitung angka korelasional ataur hitung dari nilai jawaban tiap responden untuk tiap butir pertanyaan ataur hitung $>$ rtabel, kemudian dibandingkan dengan tabel $\mathrm{t}$ didapat dari jumlah sampel dfn-2 Kelompok 1-3 atau 30-2 $=28$ tingkat signifikansi 5\%, maka didapa t rtabel 0,361 sedangkandalamkelompok 2-4 tingkat signifikansi $5 \%$, maka $29-2=27$ didapat $\mathrm{r}$ tabel 0,367 .

\section{Hasil Uji Reliabilitas}

Reliabilitas adalah ukuran yang menujukkan bahwa alat ukur yang digunakan dalam penelitian keperilakukan mempunyai keandalan sebagai alat ukur, diantaranya di ukur melalui konsistensi hasil pengukuran dari waktu kewaktu jikafenomena yang diukur tidak berubah (Harrison, dalamZulganef, 2006).Uji reliabilitas diukur dengan uji statistic cronbach alpha melalui SPSS, Nilai koefisien reliabilitas atau Alpha (Cronbach) yang baik adalah diatas 0,7 (cukupbaik), di atas 0,8 (baik), Uji reliabilitas berguna untuk menetapkan apakah instrumen yang dalam hal ini kuesioner dapat digunakan lebih dari satu kali, paling tidak oleh responden yang sama akan menghasilkan data yang konsisten. Dengan kata lain, reliabilitas instrument mencirikan tingkat konsistensi.

Tabel 2. Hasil Pengujian Reliabilitas

\begin{tabular}{|l|l|l|l|l|}
\hline No & Variabel & $\begin{array}{l}\text { Jumlah } \\
\text { Pertany } \\
\text { aan }\end{array}$ & $\begin{array}{l}\text { Nilai } \\
\text { Alpha }\end{array}$ & $\begin{array}{c}\text { Keterang } \\
\text { an }\end{array}$ \\
\hline 1 & $\begin{array}{l}\text { Attainbili } \\
\text { ty/fair } \\
\text { Attainbili } \\
\text { ty/unfair }\end{array}$ & 20 & 0,921 & Reliabel \\
\hline 2 & $\begin{array}{l}\text { Unattabil } \\
\text { ity/fair } \\
\text { Unattain } \\
\text { bility/unf } \\
\text { air }\end{array}$ & 20 & 0,945 & Reliabel \\
\hline
\end{tabular}

HASIL UJI ASUMSI KLASIK

\section{Hasil Uji Normalitas}

Uji normalitas bertujuan untuk menguji apakah dalam model regresi, variabel pengganggu atau residual memiliki distribusi tidak normal. Kalau asumsi ini dilanggar maka uji statistik menjadi tidak valid untuk jumlah sampel kecil (Ghozali, 2006). Uji ini digunakan untuk menguji apakah model regresi telah memenuhi kriteria distribusi normal atau tidak. Data dalam penelitian ini akan di uji terlebih dahulu dengan uji Shapiro-Wilk Test. Menurut Putri (2010) menyatakan bahwa distribusi data dapat dikatakan normal apabila nilai signifikan hitung >0,05 atau 5\% dengan menggunakan Software Statistical Package for Social Science (SPSS).

Tabel 3. Uji Normalitas Shapiro-Wilk Test Shapiro-Wilk Tes

\begin{tabular}{|c|c|c|}
\hline KBA & wil & Shapiro- \\
\hline & df & sig \\
\hline $\begin{array}{l}\text { FAIR. } \\
\text { UNFAIR } \\
\text { B.TARGET } \\
\text { FAIR }\end{array}$ & & $0,060^{15}$ \\
\hline $\begin{array}{l}\text { B.TARGET } \\
\text { UNFAIR }\end{array}$ & & $0,056^{15}$ \\
\hline $\begin{array}{l}\text { B.PROSES } \\
\text { EQUAL }\end{array}$ & & $0,065^{15}$ \\
\hline $\begin{array}{l}\text { B. PROSES } \\
\text { HIGHER }\end{array}$ & & 0,070 \\
\hline
\end{tabular}




\section{Uji Two Way Anova}

Merupakan singkatan dari analisis of varian adalah salah satu uji komparatif yang digunakan untuk menguji perbedaan mean (rata-rata) data lebih dari dua kelompok. Pengujian hipotesis dapat dilihat jika :

1.Hipotesis diterima apabila nilai signifikasi $<0,05$

2.Hipotesis ditolak apabila nilai signifikasi $>0,05$

Analisis TwoWay merupakan prosedur yang digunakan untuk membandingkan rata-rata dua variabel dalam satu group. Artinya analisis ini berguna untuk melakukan pengujian terhadap dua sampel yang berhubunganatau dua sampel berpasangan.TwoWay merupakan uji parametrik yang digunakan untuk menguji hipotesis berbeda (H1) atau tidak berbeda (Ho) diantara dua variabel. Data berasal dari dua pengukuran atau dua periode pengamatan yang berbeda yang diambil subjek yang dipasangkan (Ghozali,2011).

\section{Tabel 4. Rata-Rata Kinerja Pada Empat Kondisi} Eksperimen

\begin{tabular}{|c|c|c|}
\hline \multicolumn{3}{|c|}{$\begin{array}{l}\text { Panel A : Hasil ANOVA : Performance } \\
\text { sumber Variasi df }\end{array}$} \\
\hline Fairness of Budget Target & 1 & $\begin{array}{l}0,282 \\
0,600\end{array}$ \\
\hline $\begin{array}{l}\text { Fairness of Budget Process } \\
0,877 \\
\text { Panel B : Mean Performance }\end{array}$ & 1 & 0,024 \\
\hline Budget Target/ Budget Process & & \\
\hline Std.dev & & Mean \\
\hline Attainability/ Equar (cell A) & & 77,33 \\
\hline 4,895 & & \\
\hline $\begin{array}{l}\text { Attainability/ Higher (cell B) } \\
\qquad 5,202\end{array}$ & & 81,33 \\
\hline $\begin{array}{l}\text { Unattainability/ Equal (cell C) } \\
\qquad 5,066\end{array}$ & & 81,07 \\
\hline $\begin{array}{c}\text { Unattainability/ Higher (cell D) } \\
5,385\end{array}$ & & 82,50 \\
\hline
\end{tabular}

$0,600>0,05$ yaitu adanya perbedaan antara fairness terhadap kinerja berbasis anggaran dilihat dari aspek target anggaran dan dapat dianalisis bahwa hipotesis 1 memprediksi unfair budget target menghasilkan kinerja yang baik dibandingkan fair budget target, dengan mengabaikan bagaimana proses budget target tersebut ditentukan. ketika target anggaran di tentukan secara tidak adil ,memiliki kinerja yang lebih tinggi dilihat dari cell C $(77,33)$ \& cell D $(81,07)$ dibandingkan ketika target anggaran dilakukan secara adil dilihat dari cell A $(77,33)$ \& cell B $(81,07)$ tanpa mempertimbangkan adil atau tidaknya dalam proses penentuaan anggaran, hasil dari analisis anova menunjukkan budget target fairness adalah signifikan, $F(0,282)$ dan $\mathrm{p}(0,600)$, Analisis tersebut mengindikasikan bahwa target yang fair maupun unfair berbeda secara signifikan dalam pencapaian kinerja.

Dari hasil data penelitaan dinyatakan bahwasannya hipotesis 2 diterima dilihat dari nilai signifikan 0,887>0,05 yaitu adanya perbedaan antara fairness terhadap proses anggaran dilihat dari aspek proses penentuaan anggaran dapat dianalisis bahwa ketika proses anggaran ditentukan secara tidak adil memiliki kinerja yang lebih tinggi cell A $(77,33)$ \& cell C $(81,33)$ dibandingkan dengan proses anggaran yang ditentukan secara adil cell B (81.07) \& cell D (82,50), tanpa mempertimbangkan adil atau tidaknya dalam penentuaan target anggaran. Hasil dari analisis anova pada budget process fairness menunjukkan $\mathrm{F}(0,024)$ dan $\mathrm{p}(0,887)$, analisis tersebut mengindikasikan bahwa proses yang fair maupun unfair berbeda secara signifikan dalam pencapaian kinerja.

Hasil penelitian ini didukung oleh Lindquist (1995) yang menemukan bahwa tidak terdapat hubungan yang signifikan antara fairness dengan kinerja dalam partisipatif anggaran. Studi ini mendukung hasil penelitian yang dilakukan oleh Libby (2001) yang menemukan bahwa kinerja rendah ketika target dan proses penentuan anggaran dilakukan secara tidak adil. Fair budget target menyebabkan tidak adanya perbedaan kinerja antara anggaran yang ditentukan secara adil maupun tidak. Sedangkan proses yang fair tidak memberikan dampak yang berbeda terhadap kinerja dengan target yang adil maupun tidak.

Penelitian mengenai fairness masih sangat luas. Riset selanjutnya mungkin dapat mengeksplore aspek-aspek fairness lainnya yang dapat mempengaruhi sikap dan perilaku seseorang. Penambahan variabel lain yang dapat mengeliminasi perilaku disfungsional akibat dari keputusan non participative masih diperlukan. Penggunaan skenario yang lebih kompleks dan realistis serta penggunaan sample yang sesungguhnya merupakan langkah yang baik dalam pengujian yang akan datang.

Hasil penelitian ini mempunyai keterbatasan yang melekat pada penelitian ini. Pertama, metode eksperimen mempunyai keterbatasan dalam validitas eksternal, ketidakmampuan hasil eksperimen untuk menggeneralisasi simpulan penelitian secara menyeluruh. Kedua, keterbatasan waktu pelaksanaan tugas eksperimen bagi partisipan. Pada penelitian yang menggunakan metode eksperimen sebaiknya peneliti mengundang responden secara khusus sehingga dapat menggunakan waktu yang lebih memadai dalam melaksanakan prosedur eksperimen bagi responden. Hal ini untuk menghindari kurangnya pemahaman responden atas prosedur eksperimen sehingga hasil pengujian menjadi kurang optimal. 


\section{Kesimpulan Dan Saran}

\section{Kesimpulan}

Tujuan dari penelitian ini adalah untuk menganalisis apakah Interaksi persepsi fairness dan incentive yang dijadikan dalam memotivasi individu untuk berkinerja dalam mencapai target anggaran yang melalui metode Esperimen, yang dimana hubungan Fairness terhadap kinerja berbasis anggaran adalah semakin adil suatu perusahaan dalam memberikan income (berupagaji atau reward) yang sesuai dengan outcame (kinerja karyawan) maka karyawan tersebut akan merasakan puas dan termotivasi dalam meningkatkan kinerjanya. baik dari proses penetapan anggaran maupun pencapaiyan anggaran, yang dilakukan pada mahasiswa pascasarjana ilmu manajemen kampus Universitas Malikussaleh. Berdasarkan hasil analisis pengujian data dan pembahasan yang telah dilakukan maka dapat diambil beberapa kesimpulan, diantaranya adalah sebagai berikut:Hipotesis 1 diterima karna nilai signifikan lebihbesar yaitu dengan adanya perbedaan antarafairness terhadap kinerja berbasis anggaran.Hipotesis 2 diterima karna dilihat dari nilaisignifikan lebih besar yaitu dengan adanyaperbedaan antara fairness terhadap prosesanggaran.

\section{Saran}

Berdasarkan hasil penelitian ada beberapa hal yang akan menjadi saran dan masukan peneliti untuk kedepan: 1.Melakukan teknik pengumpulan data tambahan seperti wawancara dengan pihak perusahaan dengan tujuan memperbanyak jumlah responden dan melakukan pilot study untuk menjamin bahwa item-item pertanyaan dalam kuesioner dapat dipahami dengan baik oleh responden.

2.Untuk penelitian lebih lanjut dengan topik yang sama hendaknya menggunakan alat-alat statistik yang berbasis SEM (Structural Equation Modelling) 3.Perlu dilakukan pengembangan instrumen penelitian, yaitu disesuaikan dengan kondisi dan lingkungan dari obyek yang diteliti.4.Bagi Peneliti selajutnya:

A.Untuk penelitian selanjutnya diharapkan mencari waktu yang pas untuk melakukan penelitian, sehingga tidak kesulitan mencari responden dan data yang diharapkan pun tercapai.

B.Membuat tingkatan soal untuk test yang akan diuji dari, mudah, sedang dan rumit lebih efektif karena dapat membantu responden yang sudah cukup lama tidak mempelajari hal yang akan diuji, dengan menggunakan metode eksperimen harus memasukkan variabel kontrol untuk memperkecil tingkat kesalahan.

\section{DAFTAR PUSTAKA}

Yusnaini, 2010. Analaisis Fairness dan Incentive Contracting Pada Kinerja Berbasis Anggaran: Pengujian Eksperimen atas Referent Cognition Theory. Jurnal Akuntansi dan keuangan, Vol. 12, No.1

Bernardin dan Rulssel (1993) dalam Yeremias T. Keban (2004) mengartikan kinerja sebagai the record of outcomes produced on a specified job function or activity duringa specified time period. Dalam definisi ini, aspek yang ditekankan oleh kedua pengarang tersebut adalah catatan tentang outcome atau hasil akhir yang diperoleh setelah suatu perkerjaan atau aktivitas dijalankan selama kurang waktu tertentu. Dengan demikian kinerja hanya mengacu pada serangkaian hasil yang diperoleh seorang pengawai selama periode tertentu dan tidak termasuk karakteristik pribadi pegawai yang dinilai. Jurnal Akuntansi dan keuangan, Vol. 12, No.1

Folger (1986), dalam yusnaini, 2010, ketika target anggaran ditentukan secara fair, maka informasi mengenai proses penentuannya menjadi tidak penting dalam memotivasi pencapaian target. Dilain pihak, ketika target anggaran ditentukan dengan unfair, maka individu akan berusaha mencari informasi mengenai bagaimana proses penentuan target anggaran tersebut. Jika hal itu dihasilkan dari proses yang tidak fair, maka individu menjadi merasa sangat marah, sehingga kurang termotivasi unt uk mencapai target anggaran (Cropanzano dan Folger 1991), Jurnal Akuntansi dan keuangan, Vol. 12, No.1

J Stacy Adam tahun 1963. Dalam latif 2007, Teori ini menganggap bahwa individu membandingkan masukan dan keluaran pekerjaan mereka dengan masukan atau keluaran orang lain dan kemudian berespon untuk menghapuskan setiap ketidakadilan (Ikhsan A dan Iskhak M, 2005). Peran Keadilan selama anggaran telah difokuskan pada penelitian akuntansi perilaku, seperti penelitian Lindquist (1995) yang menemukan bahwa suatu organisasi cenderung ingin mempertahankan keadilan dalam proses anggaran.

Leventhal, 1980. Dalam latif 2007. Keadilan prosedural berhubungan dengan persepsi bawahan akan suatu bentuk keadilan dari semua proses yang 
diterapkan oleh pihak atasan dalam perusahaan tersebut dan untuk mengevaluasi kinerja mereka. Mengkomunikasikan umpan balik kinerja dan menentukan apakah penghargaan yang mereka terima seperti promosi atau kenaikan jabatan dan peningkatan gaji (McFarlin \& Sweeny, 1992).

Thibaut dan Walker. 1975, dalam latif 2007 membantah bahwa prosedur yang berbeda akan dipandang secara berbeda pula oleh individu yang berbeda dibawah kondisi lingkungan yang berbeda pula.Sehingga mereka menjelaskan bahwa prosedur yang berbeda dibutuhkan untuk menempatkan berbagai jenis permasalahan yang berbeda yang berpotensi muncul, Karena studi ini berdasarkan pada sistem keadilan hukum untuk meredakan suatu permasalahan atau pertikaian hukum., mereka menganggap dan mempertimbangkan lingkungan individu menjadi nilai penting. Menurut mereka, untuk mengatasi suatu pertikaian atau permasalahan akan kepentingan pribadi dan distribusi hasil akhir, maka prosedur bernilai tinggi dalam pengendalian proses atas sebuah konflik sebaiknya digunakan. Karena prosedur ini meskipun mengalami bias dalam pengumpulan informasi, namun menjamin dan memastikan pertimbangan lingkungan individu yang diperlukan untuk memaksimalkan suatu keadilan' (Thibaut dan Walker, 1975). Karenanya, keberadaan pengendalian konflik (yang berlawanan dengan pihak ketiga) memiliki proses untuk membantu mencapai sebuah keputusan (penge dalian proses) dianggap berguna dalam menilai suatu keadilan. Dengan kata lain, keadilan prosedural dipengaruhi oleh keberadaan konflik yang dibiarkan terjadi untuk memberikan solusi atau pemecahan terhadap suatu konflik legal atau konflik hukum.

Yusnaini, 2010. Labaso, Abdulhamid, 2013 Fairness adalah suatu keseteraan dan kewajarandalam perlakuan adil dan setara dalam memenuhi hak-hak stakeholder yang timbul berdasarkan perjanjian serta peraturan perundang-undang yang berlaku.
Jurnal Akuntansi dan keuangan, Vol. 12 , No.1

Labaso, Abdulhamid, 2013. Yusnaini, 2010. Incentive Contracting adalah suatu pemilih yang memberi kompensasi tahapan kepada kontraktor berdasarkan kinerja eksekusi biaya, jadwal, kualitas,dan keamanan sesuai dengan persyaratan dan ketentuan kontrak,ada dua kemungkinan insentiv harga tetap,dan kontrak insentiv penggantian biaya.kontrak insentiv harga tetap lebih disukai bila biayanya melampaui persyaratan kinerja. Vol. 13, No.2

Labaso, Abdulhamid, 2013. Analaisis Fairness dan Incentive Contracting Pada Kinerja Berbasis Anggaran: Pengujian Eksperimen atas Referent Cognition Theory. Jurnal Akuntansi dan keuangan, Vol. 13, No.2 